\title{
International Marketing Strategy as Determinants of Export Performance in Nepalese Handicraft Sector \\ Binod Lingden ${ }^{1}$ \\ ${ }^{1}$ PhD Scholar| Mewar University, Rajsthan India binling66@gmail.com
}

\begin{abstract}
Increased globalization of trade has led to a growing number of firm's focus on high-growth export market. The spotlight on activity export has also attracted the attention of academics. This study aims at explaining the marketing strategy as determinants of export performance in Nepalese handicraft sector.
\end{abstract}

Keywords: International marketing strategy, export performance, handicraft sector

\section{BACKGROUND}

Export is an imperative in contributing to a nation's economic prosperity. It leads to in an increase in domestic production, economic growth, and the fulfillment of foreign currencies to meet the cost of import. Export is an most important strategy in ensuring a firm's survival or growth, and firms may achieve competitive advantage in global markets (Navarro et.al, 2009). Various firms in recent times have focused further attention and allocated moreresources in order to export their products to international markets (O'Cass, 2002). Therefore, the objective of majority of the firms and national governments is to expand export.

Identifying the determinants of export performance is a strategic move, which has attracted attention for exporters, export managers, policy makers and researchers (Mohamad, et.al; 2009). Many previous literatures have identified numerous variables as determinants of export performance which they conclude depends on various classifications such as firm's structure or internal factors, international environment or external factors and international marketing strategy or export marketing strategy (Cicic, et.al , 2002). Among those variables, to compete in the global market, international marketing strategy greatly contributes to decision making regarding which marketing strategy to employ, which markets to enter, and how to enter these markets (Rahman, 2006).

In the context of Nepal, although it has huge potential for exports, it tends to face serious challenges because of cut-throat competition. Very few or no data exist to suggest that international marketing strategies employed by Nepalese business particularly in the handicraft sector, have influence on export performance. Nepalese export business analyzes the export data in its annual summary. However, it does not analyze international marketing strategies that influences export performance. The influencing factors are undetermined. It is imperative to identify the influencing factors that can boost export performance.

\section{OBJECTIVES}

The specific objectives are

- To analyze the international marketing strategy of business in the handicraft sector.

- To measure the influence of international marketing strategy on export performance.

- To recommend international marketing strategy that contributes to export performance.

\section{THEORITICAL FRAMEWORK}

\section{Export performance}


Export performance, which is the dependent variable in this research, is defined as the degree to which firm's objectives (both strategic and economic) for selling a product into a foreign market are accomplished through the planning and execution of international marketing strategy, and it measures the result of a firm's movements in international markets (Cavusgil and Zou, 1994). The understanding of export performance is significant at firm level because export strengthens financial performance and competitive edge, exploitation of productive capacity and provides groundwork for future international expansion (Lu \& Beamish, 2001).

\section{Measure of export performance}

Review of international marketing literature highlights three performance dimensions considered to be the most interesting for corporate and business unit managers. The first is effectiveness, in terms of business's product and programme relative to competitors. Indicators such as sales growth can be the measure of effectiveness. The second is efficiency which is concerned with the outcome of business programmes relative to the inputs employed to implement them. Profitability is the key measure of this dimension. The third dimension is adaptability in terms of how the business responds to changing conditions and opportunities in the environment (Walke and Ruekert, 1987).

\section{International marketing strategy}

International marketing strategy is the independent variable in this research. International marketing strategy deals with management of all components of the marketing mix. The linking of marketing strategy to export performance has been one of the most widely investigated topics in international marketing research. (Berthon et al., 2012). The international marketing strategy elements are product, price, place and promotion (Mohamad et.al., 2009).

\section{CONCEPTUAL FRAMEWORK}

A number of studies have attempted to identify key factors that contribute to successful international marketing. Specifically, research attention has focused on four elements - the company's export product, pricing, distribution, and promotion strategy. The relationships of these groups of variables with export performance have been conceptualized in several studies (Cavusgil and Zou, 1994). Based on the literature review, this study seeks to answer the following research question; Which international marketing strategy contributes to export performance of Nepalese business? The proposed conceptual framework between international marketing strategy and export performance are presented in the figure below:

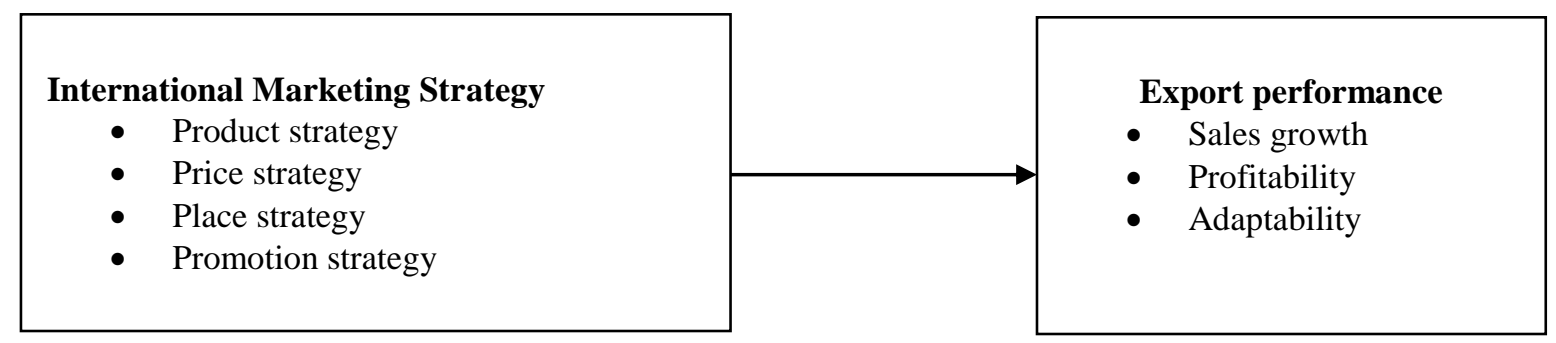

Figure: Proposed Conceptual Framework

\section{BIBLIOGRAPHY:}


Cavusgil, S.T., and Zou, S. (1994). Marketing strategy-performance relationship: an investigation of the empirical link in export market venture. Journal of Marketing, 58(1) 1-21.

Cicic, M., Patterson, P., Shoham, A., (2002). Antecedents of international performance: A service firms' perspective. European Journal of Marketing, 36 (9/10), 1103-1118.

Lu, J. W., and Beamish, P. W.( 2001). The internationalization and performance of SMEs. Strategic Management Journal, 22 (6/7), 565-586.

Mohamad, O., Ramayah, T., and Kim-Soon, Ng. (2009). Exporting to China and Asian countries: Perceived advancement in marketing competencies and export performance. Journal of US-China Public Administration. 6 (1), 34-45.

Navarro, A., Losada, F., Ruzo, E., Diez, J. A., (2009). Implications of perceived competitive advantages, adaption of marketing tactics and export commitment on export performance. Journal of World Business. 45 (1), 49-58.

O'Cass, A., Julian, C., (2003). Examining firm and environment influence on export marketing mix strategy and export performance of Australian exporters. European Journal of Marketing. 37 (3/4), 366-384.

Rahman, S. H. 2006, 'International market selection process: An investigation of the relevance of business operating environment', Journal of International Business Research, vol. 5, no. 1, pp. 73 -86. 